\title{
ARCHITECTURE IN THE ISLAMIC CIVILIZATION: MUSLIM BUILDING OR ISLAMIC ARCHITECTURE
}

Ayat Ali Yassin

Dr. NangkulaUtaberta

\author{
Architecture Department, Faculty of Engineering \& Built \\ Environment \\ UniversitiKebangsaan Malaysia (The National University \\ of Malaysia] \\ UKM-Bangi, 43600, Selangor
}

Architecture Department, Faculty of Engineering \& Built Environment

UniversitiKebangsaan Malaysia (The National University of Malaysia]

UKM-Bangi, 43600, Selangor

\begin{abstract}
The main problem of the theory in the arena of islamic architecture is affected by some of its Western thoughts, and stereotyping the islamic architecture according to Western thoughts; this leads to the breakdown of the foundations in the islamic architecture. It is a myth that islamic architecture is subjected to the influence from foreign architectures. This paper will highlight the dialectical concept of islamic architecture or muslim buildings and the areas of recognition in islamic architecture. It will also widen the knowledge in the characteristics of each point in time according to the stages of islamic architecture from the prophetic age moving through the architecture outside the city of Medina, the Caliphs, the Umayyad, Abbasid, and architectural models by spatial and time periods, taking Iraq as the example to explain how the Islam influents on architecture and vice versa.
\end{abstract}

Keywords: Islamic Architecture

\begin{abstract}
Abstrak
Masalah utama pada teori arsitektur islam dipengaruhi oleh beberapa pemikiran barat, dan stereotype arsitektur islam yang mengacu kepada pemikiran barat; Hal ini mengantarkan kepada pecahnya pondasi arsitektur islam. Pernyataan bahwa arsitektur islam bersubyek pada pengaruh arsitektur luar merupakan mitos belaka. Makalah ini akan memaparkan konsep dialek dari arsitektur islam atau bangunan muslim dan daerah yang terkenal dengan arsitektur islam. Selain itu juga memaparkan masa perpindahan kenabian melalui arsitektur di luar Kota Madinah, Khalifah, Umayah, dan Abbasiyah, serta model arsitektural dengan periode ruang dan waktu, mengambil Irak sebagai contoh untuk menjelaskan pengaruh islam pada arsitektur dan sebaliknya.
\end{abstract}

Kata kunci: Arsitektur Islam

\section{Introduction}

The islamic architecture is not determined, it is not standards and forms, not limited to patterns applied in countries conquered by the Muslims. The more we understand about its architecture, it is recognized that the islamic content is created to establish the building character with a distinct identity. The relation of time and place differs within the architectures created in various Muslim countries. Despite the diversity of solutions, the original feature and the similarity of the surrounding environment weather, construction materials and designer thought are maintained. What distinguishes them is that they bear features consistent with the requirements of rights and traditions and the environment in which they live in. These are perfect solutions to their needs. However, they are characterized by Islamic architecture and Islamic art in general, therefore with any common unit collected ,we can identify any piece produced under the Islamic civilization in any country from the Muslim world. Perhaps this is the secret of the superiority of Islamic civilization and artistic ability to paint art products in all countries- there will always be one distinct character of each country.

There are different definitions on the term Islamic architecture or Muslim architecture, but in general the concept of Islamic architecture refers to the characteristic of building used by Muslims to serve as their identity ${ }^{1}$. The creation of this 
architecture dates back to Islam and in areas where it arrived as the Arabian Peninsula, Egypt, the Levant, Arab Maghreb, Turkey, Iran, and others; those under prolonged Islamic rule such as Andalus (Spain now) and India. The Islamic architecture and characteristic singled mainly from the Islamic region and scientific renaissance that followed. They vary from region to region according to climate, architectural, and cultural heritage in the former region, where the spread of open courtyard in the Levant, Iraq, and the Arabian Peninsula ${ }^{2}$ disappeared while the architecture in Turkey is a result of weather condition, in Yemen is due to the architectural heritage ${ }^{3}$.

\section{Related Work}

Many researchers have focused mainly on the islamic architecture and the different terms that were used in the building of Islamic civilization. These differences have raised several questions, which we will attempt to answer them ${ }^{4}$ : Do the islamic civilization develop their own architecture or is it the result of the regional building models evolution which extends its roots to the heritage of those cultures? We find that Lame-Pooles ${ }^{5}$ used the term architecture in his Alsarasinah book (Hanbook of Sarascenic Art) and the origins of this term from the ancient Greek was also used by Ptolemy. Martin S. Briggs ${ }^{6}$ used the term Mohammedan architecture in his book (Mohammed an architecture in Egypt and Palestine), Arabic architecture (Arabs), Arab architecture: because of the overlap between Islam and the Arabs. Gostaph Lepon ${ }^{7}$, who wrote the book Civilization of the Arabs included all their productions and the architectural but was criticized by Lan Poulis, Spears, Ferguson, and Rifuera for determining the Arabism just by including people who live in the Arab and Peninsula, from Morocco to Iraq. The abolition of the Persians architecture, Indians, Chinese and others (Moorish architecture) which was used by the Spaniards ${ }^{8}$ on the Moroccans, then to Muslims specifically, and expanded to call for all the Muslims from the Philippines and the Pacific Islands. Architect Raaft Chadderchi ${ }^{9}$ defined the term islamic architecture as the cultural formulas more than it is religious, a term that is inappropriate and contradictory, and there was no unity in design between different environments. However, Turkish (Spirochristov) ${ }^{10}$, denied the existence of architecture associated with Islam and considered the product of an architect is in pace with the product of the countries that came after solutions of Islam in all parts of the world .Architect Hassan Fathy stated ${ }^{11}$ (the movement of the hands of the designer does not come from the mind only, but about feeling, spirit and creativity of the designer fingers, it is the creativity of the sprit), so the term Islamic architecture is the most widely accepted because it is comprehensive of all this creativity which is spiritual, not physical tangible. Architect Abdel Baki Ibrahim ${ }^{12}$ believed that the term launched by islamic architecture and the Orientalists linked the religious aspect of this term and the term Muslim building gives a deeper understanding because it connects architecture and environmental psychotropic economic rules. Some theorists who believe that the term islamic architecture or islamic building are linked to islamic rulings fixed in Islamic law, and the term urbanization of Muslims shall be outside the framework of Islamic law. This means that the architecture with the values of 'use' where each building used by the Muslims is taken as their architecture. It is clear that what is produced by a civilization dominated by Islamic culture, which was formed through the interaction of elements of this culture (religion, art, literature and society) and the building used by Muslims (for example the members of the Muslim community using houses in European cities) must we call it "the Muslims Building"? It does not take into account to any Islamic element. This confusion between what is functional (shared by various human cultures)and what is cultural and stems from the privacy of its techniques and composition of the spatial and aesthetics originated from this culture, thus rejected the term "architecture Muslims" only when referred to the architecture of everyday life that are formed as a result of the culture of Muslim daily with its own specificity, without doubt, but this architecture cannot be relied upon to record the Islamic cultural.

\section{Architecture in the Islamic Civilization}

The reduction of architecture that evolved in the Islamic civilization in one term is the underestimation of civilization and cultural achievement produced by the islamic civilization. The only decoration and adornment configuration is a complete deviation from the cultural depth provided by the islamic civilization. The use of the term "architecture in the Islamic civilization" as a general framework, while likely to use the term special care of the maintenance of each historical period on the unit such as "Architecture of Islam" or "Architecture Umayyad Early" of "Architecture Abbasid" as well as we can in this regard, looking deeply and in detail in the buildings' differing features that arose over the islamic civilization: geographical and temporal differences between them are models of architecture in different regions of the Islamic call to reach a comprehensive and logical point to islamic architecture.

\section{Islamic styles and reflection on architecture in Iraq}

Iraq had a great role in the prosperity of the Arab Islamic civilization that has placed it among the countries of the world. Arab-islamic civilization grew in Iraq in the Abbasid era, and quickly evolved and expanded its facilities. Various researchers tend to believe that the reason behind the fact is that Iraq has the background of an advanced 
civilization. This is reflected in the mosques that were centers of radiation science that have renewed and expanded famous cities Baghdad, Basra, Kufa, Mosul, and other Iraq cities. They have also flourished the life and many religious and civic buildings and reflected the buildings and islamic arts in the Islamic nation; in Iraq in particular. Intellectuality and creativity are to be adopted by the designer in the Muslim architectural planning and decoration, commensurate with the greatness of the heavenly message.

The real development of islamic civilization did not start only after the people of ancient civilizations such as the Iraqis, Egyptian, Persians, and others converted to Islam. Religion becomes a source of excellence, and integrated into the craft and creative architecture with Islamic values to reflect the Islamic architecture.

There is no doubt that islamic architecture has inherited many experiences from ancient civilizations preceding them, like that of other stages of development prior to starting a new phase. They have their own methods and types of buildings, new and distinctive, as well as their methods of construction that distinguish them, as well as decorative elements and aesthetic, and thus the birth of the distinctive Iraqi islamic style.

\section{Architecture in Modern Prophetic}

In distinguishing the islamic architecture, it appears to be very simple and strict. Two special islamic architectures in this era that reflect these features are the Quba Mosque and the Prophet's Mosque. In the Quba mosque, we find examples of the simple in architecture, and the building of the Prophet's Mosque is in the form of a large open courtyard, covered some parts of the palm leaves placed on the branches of the palm, which stretch on the pillars of the palm, very simple and strict ${ }^{13}$. Even after having undergone a facelift, the mosque retained the same simplicity as compared with the mosques in this period. This is a result from having served many functions: as a hospital courtyard and a camp for prisoners, and the homes of some of the companions and the Muslims who worship in it.

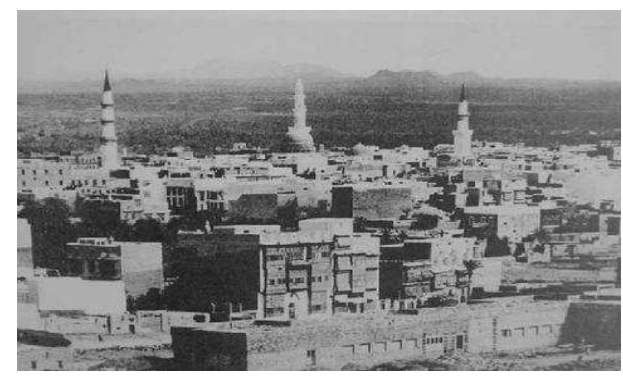

Figure 1. Prophet Mosque

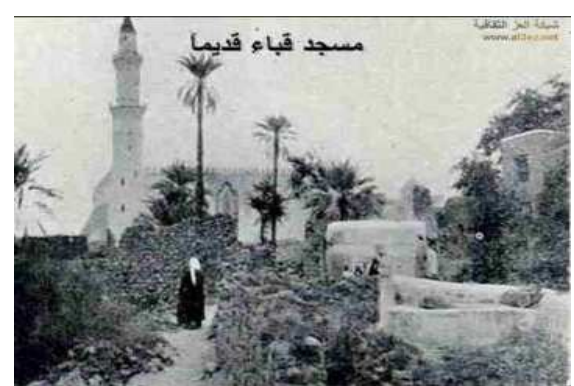

Figure 2. Quba Mosque

In Iraq, we can see very little changes in the Prophet buildings. The changes are confined to the Mecca and Medina basic principles of the Islamic development and city planning as not all the people of Iraq are Muslims. Islam was limited to some people. It was a change at the level of housing to isolate the individual, public and private spaces. All forms of art, graphics and motifs on the facades of houses were removing.

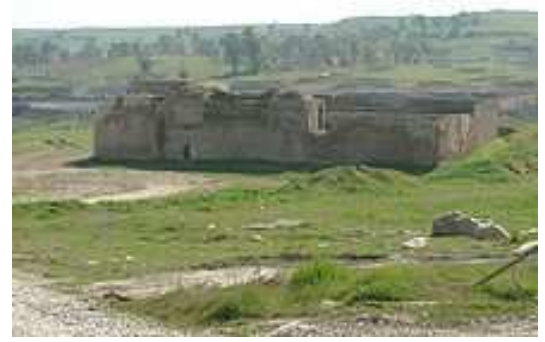

Figure 3. Mar Elea Monastery Near Mosul

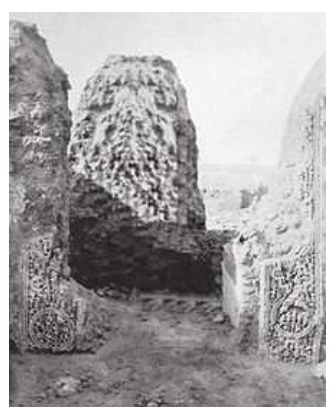

Figure 4. One of the Houses in Alhira

\section{Building in era of Caliphs and Umayyad}

The death of the Prophet (PBUH) and the end of the succession of companions, ended the era of simplicity and rigor to begin the Umayyad dynasty ruled from the Levant and its capital, Damascus. After the era of prophecy, every thought is a judgment based on the Qur'an and the Sunnah and its legal provisions. This was also the case in the architecture except for Syria, Palestine and all 
Levant, which are Christian Counties and part of the Byzantine Empire, the first of the Umayyad architecture that was greatly influenced by the Christian is clearly reflected in the Umayyad Mosque in Damascus. In rebuilding the Al-Aqsa Mosque, the Dome was of a Rock in a manner to indicate Christian influence with the introduction of some new features of Islamic architecture by adding writings of the Quran or the hadith in the decoration of mosques.

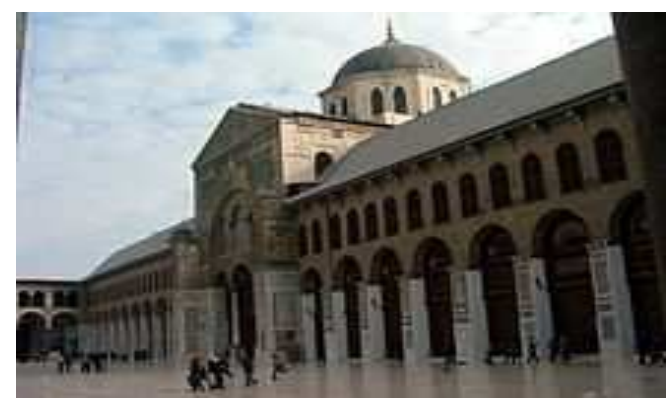

Figure 5. Mosque al Umayyad in Damascus

Among The Dome of the Rock, Al Aqsa Mosque, the Umayyad Mosque in Damascus, and the Mosque of Kairouan, the Dome of the Rock is least affected by the Christian (Byzantine)architecture.

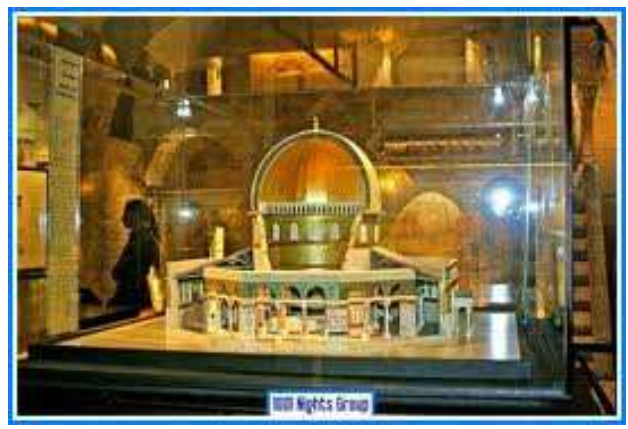

Figure 6. the Dome of Rock

Every thought that came after the era of prophecy is a judgement based on the Qur'an and the Sunnah. During the Prophet's era, building study was specialized due to the presence of the Sunnah and conditions of the Qur'an. Even buildings in the post-Prophetic era were based on the judgement. In Iraq, it is said that one of Caliphs is to design a city of Basra (16AH), and the city of Kufa (17AH). The basis of the construction was military. We note that the mosque was located at the center of the city and that the tribes had created for themselves a land around the mosque with the market situated away from the mosque. The houses significantly confirmed the juxtaposition of spatial and principality. This was the Prophet Muhammad's approach; either at the level of housing did not change radically, except for some converted spaces, which was dedicated for family members to perform prayers and worships and some spaces for private events.

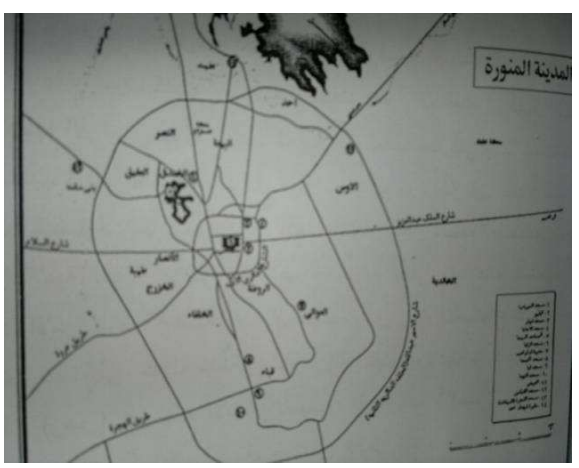

Figure 7. Plan for ALmadenaALMoura in the Righteous Caliphs

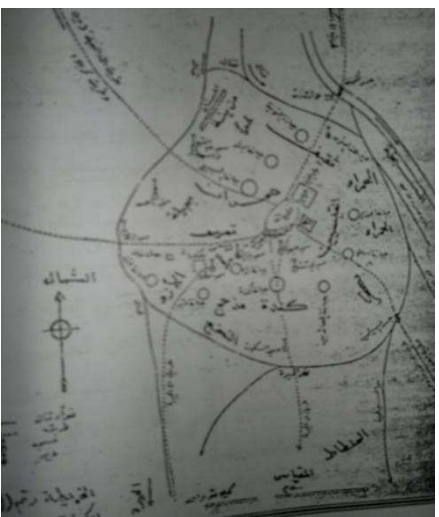

Figure 8. Plan for ALKuffa City

In the Umayyad period, Damascus was the Umayyad dynasty capital, and was known as the Umayyad style or Shame style, which marked the establishment of palaces and attention to decoration. It was no longer a mosque-centered city as in the past. The separation of home principality from the mosque because of the differences that occured in the beginning of the Umayyad rule, the focal attention deficiencies occured since the beginning of the Umayyad ruling. The appearance of the yard in the center of the house and arranged wan, located symmetrically on the left and right suites, were works of extinction which represented the class known as Hairi. Due to the evolution and spread of confusion in the palaces in Iraq, and the spread of the Umayyad period in some houses of Kufa, Waist and Benny Gided housings, buildings in Iraq in addition to the above, we also observe the emergence of minarets with square columns. Domes are based on a square base; abound in the corridors of the landscape mosaic. The examples are: Palace Om Areyev in Kufa, the palace built by Osakav Jnied in Diyala, and Shaba Palace in the city of Basra. 


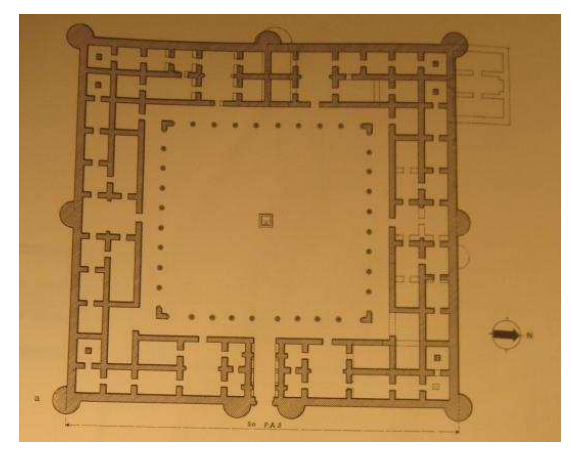

Figure 9. Plan for Palace in Iraq

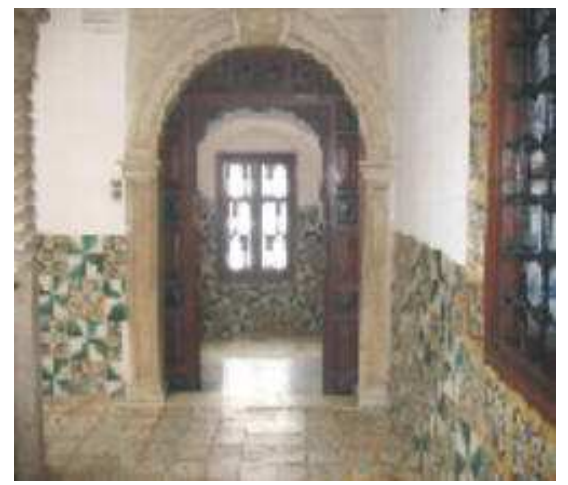

Figure 10. Entrance for Shaba Palace

\section{Building in Al Abbasid Era:}

The fall of the Umayyad dynasty in Damascus made way to the beginning of the reign of the Abbasid state, which ruled the country from Baghdad, one of the most affluent cities in Islam .They affected the prosperity of the Abbasids and the simple Islam method in Umayyad architecture, ancient civilizations of Babylon and Mesopotamia (Iraq) and Persian. The fact was the Abbasids' styles were private domes and minarets, which were developed during the Umayyad Islamic dynasty. The Abbasid model was also unique in the shape of the columns, beams and decorations between pillars in the form of large domes of the mosques. The best examples of the Abbasid mosque models are the al Jama mosque in Samarra, and the Mosque of Abu AlrivhDilv, both in Iraq, and the Ibn Toulon mosque in Cairo.

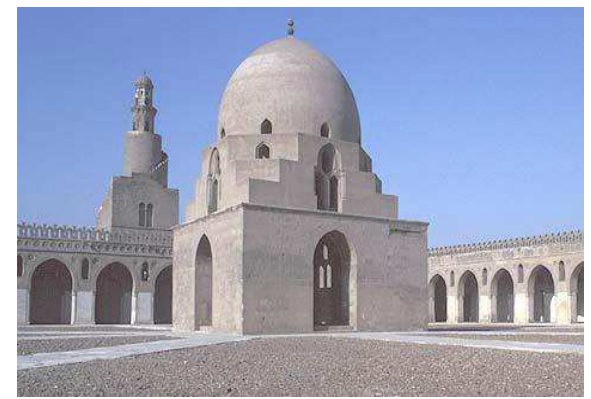

Figure 11. IbnToulonmosque in Cairo
The evolution of architectural thinking in this era, has given us the architectural models creator, and specifically in Iraq, as the Kufa was the center of the Abbasid and later widening the Islamic tide to many parts of the territory: north-southeast-west. Built by Baghdad caliph, Abu Jaafar AlMansour, was a fortress in a form of a circular shape which gave flexibility in controlling parts of the city equally with four gates. This gate set up is known since the ancient Babylon. The order of functional cities in this era (Baghdad and Samarra) was according to the thought of the Abbasid caliphs, so they are a reflection of domestic politics on the functional organization of the city as well as buildings complementary to this thought. The mosque was surrounded by accomodation, government departments commercial areas at the gates.
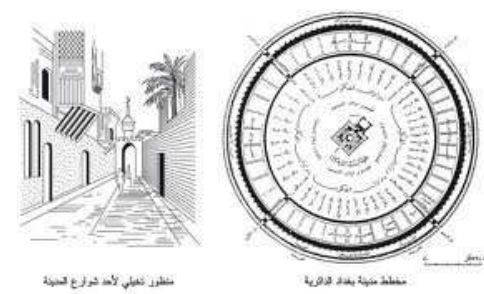

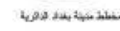

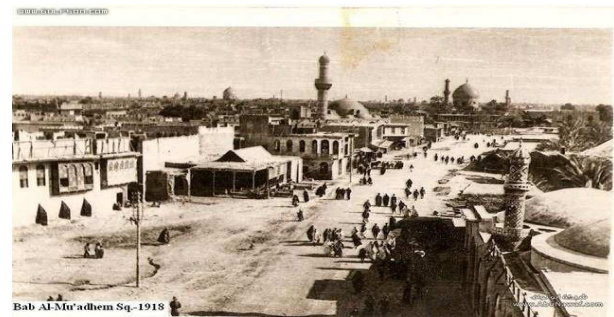

Figure 12. Baghdad retained

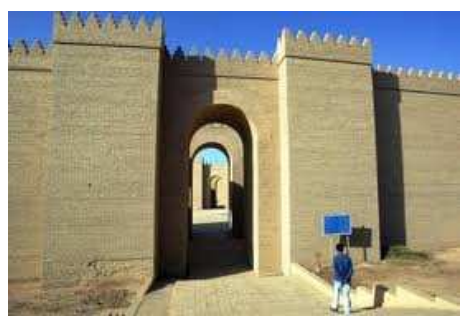

Figure 13. Babylon Gate

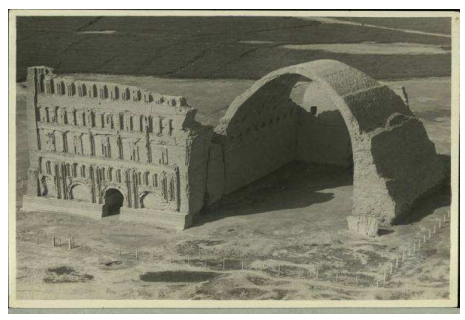

Figure 14. Baghdad Retained Gate 
In the city of Samarra, built by the caliph (Mutawakkil) was a rectangular city known as the Tigris River. One aspect of the city, as a defense, the Abu DLF Mosque is located in the outskirts of the city and not in the center as it was known before, next to the Palace of the caliph. We can observe the surrounding of the mosque are housing of the Army Leader, the king's entourage whereby the public housing is situated on the other side of the city. The markets are large and distributed, taking into consideration issues of security to reduce human crowd in a particular place. It is also noticable in the city of Samarra, streets appear as the greatest runs through the city with the width of $200 \mathrm{arm}$ to facilitate the gathering of army in case of emergency. It is not limited to buildings that were constructed in this era as Iraq had already reached its prosperity and excellence of Islamic civilization. However, the creativity peaked not only in Iraq, but also in all the cities that opened at the hands of Muslims. Perhaps the mosque of Samarra, is one of the most unique Muslim architectural creations where the outer walls of the mosque are twisted and This is considered by many researchers as a simulation of the ziggurat temples in the ancient Iraqi civilization days of Assyrian and Babylonian.

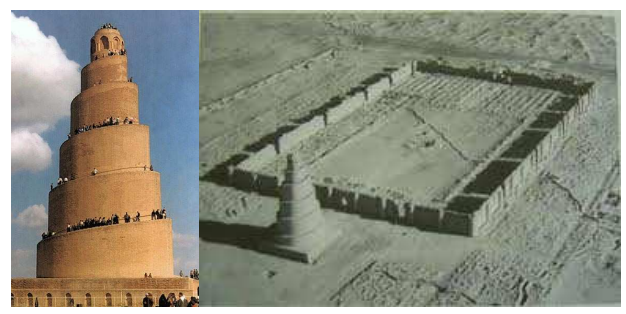

Figure 15. Mosque of Almutawakkil

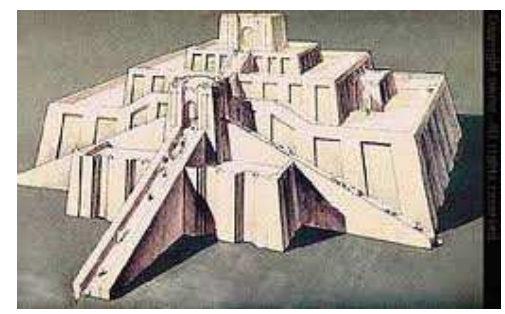

Figure 16. The Ziggurat

\section{Mustansiriya Madrasah}

When we talk about the Abbasid period, we must stand on the work of art none other than Mustansiriya in Baghdad that was built in $625 \mathrm{AH}$. It was the first school built gathering the four schools, not only on the teaching of theology and jurisprudence but was also the first university in the world. It was the nucleus of cultural in the city as a whole. We could see from the analysis done on public and private functions that the functional division with responsive occupants and nature, where you select the public spaces and semi-public and semi-private and private. This is a reflection of the thought of the Abbasid, which we have observed in urban planning. The school gate, which is characterized with the interface high as to indicate the entrance, built on the optical axis of the chapel to be the first public space. The transition from the level of public space, the city's public space at the school level Iwan right and Iwan left, then a special requested classroom, a private space which are the bedrooms and a breather, and a living room for students and teachers were chosen as rectangular to fit with the events and proportionality and the amount of elongation. This indicates the sensitivity towards ample space and movement for visitors, or to a request to estimate the space needed for the prayers and lessons, without any interference from the movements. There were equal quarters allocated to the doctrines of the four that were once convergent places in Baghdad, and so he wanted Mustansir to provide equal opportunities for students according to their affiliation. We believe that form and function were the result of thought.

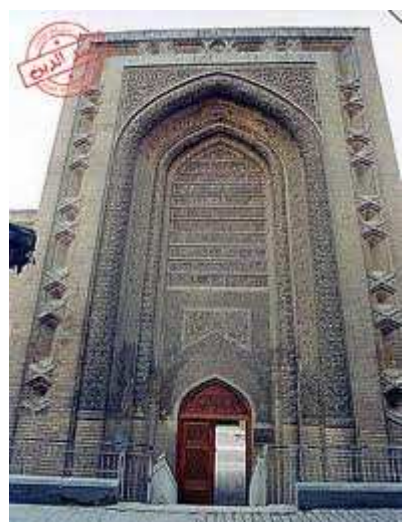

Figure 17. The gate of Mustansiriya

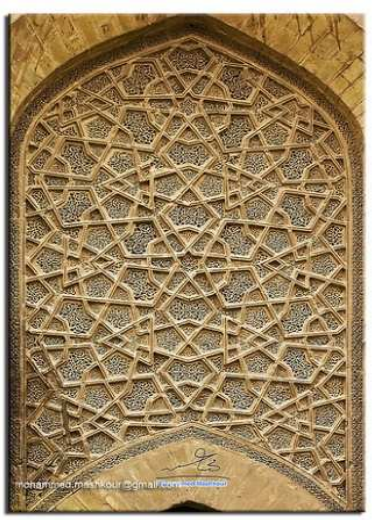

Figure 18. Detail of the Gate 


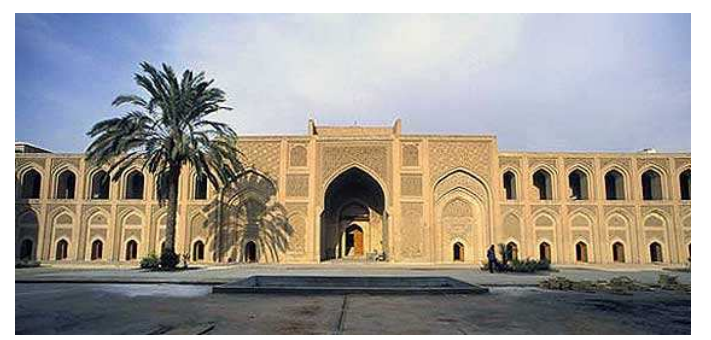

Figure 19. AlMustansiriya

\section{Fashioned by region and counties}

- Marrakech and the Andalusia-style (which dates back to the people of North Africa and Andalusia).

- Fatimid-style relative to the Fatimids in Egypt.

- Saladin-style relative to the Ayyubids in Egypt.

- Mamluk style relative to the Mamluks in Egypt.

- Asaljqa model relative to the Seljuk of Iran

- Persian Mughal style relative to the Mongols of Central Asia and the country of Persia.

- Safavid style relative to the Safavids in Iran.Indian

- Mughal style relative to the Mughal India.

- Mughal-style Turkish relative to the Mongols of Central Asia.

- Model relative to the Pashto Pashto tribes in Afghanistan.

- Ottoman style.

We can see Baghdad has undergone the rule of Albuehi, and admitted that since the Caliph invaders arrived, some physical movement was going on in Baghdad, limiting their role in urban development. The role was the basis for the elite people who were on a high level of civilization who were compared to the invaders. They built house peacocks, the square home and octagonal house, reconstructed Baghdad and the palaces, mosques and hospitals.

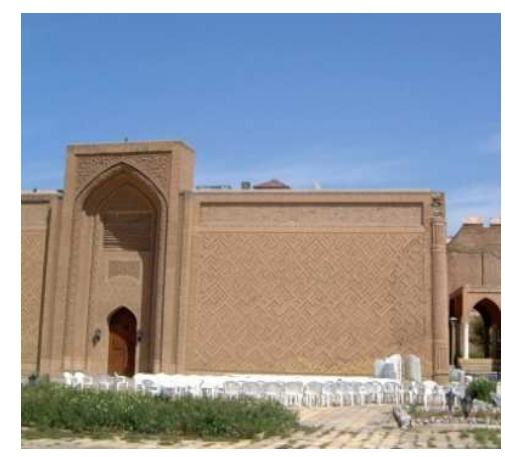

Figure 20. Caliph Palace (House Peacocks)

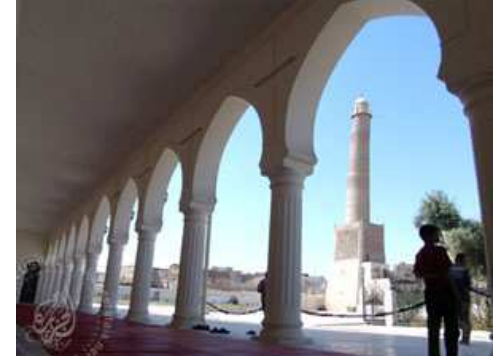

Figure 21. Nouri Mosque and The lighthouse Alhaddaba

Then came the ruling of the Seljuk (447 $\mathrm{AH} / 1055 \mathrm{AD})$, famous for building a regular school, including regular Baghdad was built in the reign buildings, a wide variety of mosques, schools, walls, baths, palaces, and the role of large. Unfortunately, most of those buildings ceased to exist, leaving only a few including the Nouri Mosque and the Lighthouse of al hadaba, Majahda mosque, Imam Yahya bin QasimBadr al-Din Palace and Mosque of Arbil, leaving only a minaret.

From the late period of the Abbasid to the free-Khalifa Nasser al-Din Allah, Iraq and other important parts of the Muslim world under the ruling of the Seljuk until the fall of Baghdad in (656 AH / 1255 AD), were the brightest periods in the history of Arab-Islamic civilization. It has returned to the succession prestige land status, and it raised the status of Baghdad, and many construction and reconstruction. As examples are the Alkhvavin mosque, alKarkhi mosque.

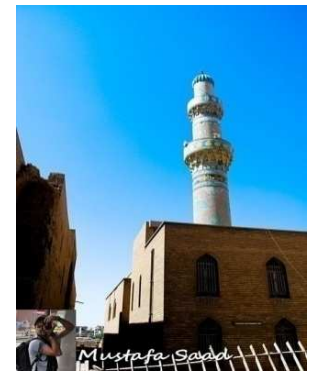

Figure 22. Alkhvavin Mosque

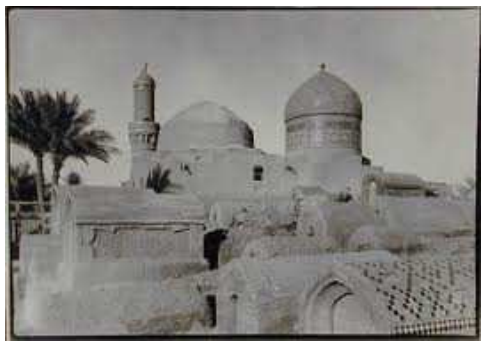

Figure 23. Alkarkhi mosque 
During the Mongols attack on Baghdad, Hulagu suffered vandalism to their heritage buildings. After a short period of its fall, some of its buildings were resumed. New set ups and new buildingsalso took place: minaret of the Mosque of the Caliphs (market spinning), new school reefs, Khan Murjan and some fields, schools, mosques and markets. Nevertheless, among thosethat were defected, some of which still exist are the most famous of these Schools, School of Morgan, the Alovaúah School and mosques such as the Acoli Mosque, SE mosque, Nomani mosque and, the Syed Sultan Ali mosque.

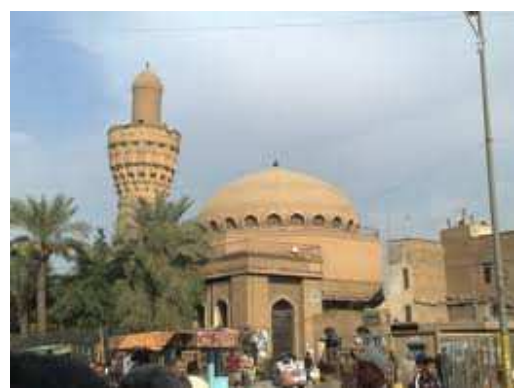

Figure 24. Mosque of the Caliphs

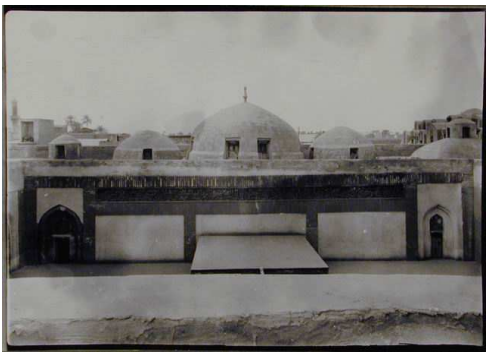

Figure 25. School of Morgan

The Ottoman Empire was interested in some of these governors and sultans reconstruction of mosques, shrines and schools, some of which still exists today,the establishment of scientific institutes, including the Rashid military Institute during the Mamluk era, which lasted to the year (1247 AH / 1831,) The reconstruction of the Wall of Baghdad after demolition and sabotage, was built on the western side of Baghdad with a wall and a trench. Others that were renewed were the Kingdom House (palace), and alqishleh watch, and finally the school of Sulaimaniyawasbuilt.

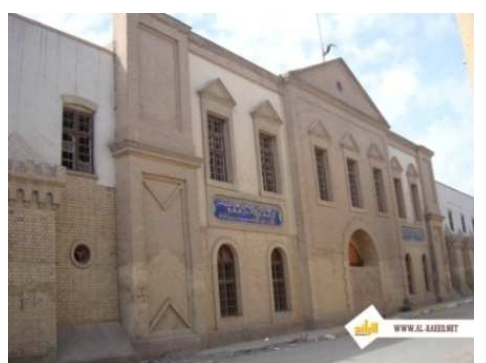

Figure 25. Kingdom House (Saraya) Alqishleh Watch

\section{Conclusion}

We can see the evolution of form and function over time that depended highly on the circumtances of the political and cultural lives of the population. The label (Islamic architecture) goes back to the nineteenth century. As Western Orient called it, a concept and named after the Islamic cultural heritage, and not a condition where the Islamic faith isenshrined.The Muslim building refers to the product of Muslims where shapes are mixed with the thought that moves the qualities and evolves with time according to the variables.

It is also noted that the Muslims practice paying respect to the norms of all people, even in the architecture and crafts especially if it does not conflict with the principles of the Islamic religion and Semitism that is so-called contemporary. The Muslims create something from their principles and their time, if theyconsume what is produced by age only, without taking into account their privacy it will be de-identity. We note that the aesthetic phenomenon in Islamic architecture (the fact that it was wonderful to be compatible with the reality of the necessities) is not the ultimate destination for architecture because that will bring to the deviation in the beauty. What distinguishes Islamic architecture is it protects itself from factors that are exposed and meet the needs of its users.

Generally, in the different Islamic eras, we can focus on many forms for a concept, such as the police concept, society, and economic so we can ensure and proof the changes in Islamic architecture is always suited for concepts of every existing era.

\section{Reference}

1 Dr. Alarabi Hassan Bouayad. 2007. The Reference Architecture We Have a Reference Text. Aharrov Magazine. Rabat

2 Asad Yakoub Gogo. 1989. The Privacy of Iraqi Architecture. Seminar In the Privacy of Contemporary Arab Architecture. Baghdad

3 Moustafa Saker. 1988. The Cities In Islam part 2. Baghdad: Dar Al Salasel for Printing, Publishing and Distribution

4 Dr Ali Thouni. Islamic Architecture,Terminology of Islamic architecture and The Early Concept

5 Lame- Poole. 1875. Handbook of Sara scenic Art

6 Martin S.Briggs. $1882 . \quad$ Mohammedan Architecture In Egypt and Palestine

7 Gostaph Lopon. Arab Civilization

8 M. Saladin. Manual De Art Musulman

9 Rafat Algadargi. 1995. Dialogue the Structural In the Art. London: Riad Al Rayes of Books and publishing

10 Dr Ali Thouni. Islamic Architecture,Terminology of Islamic architecture and The Early Concept

11 Dr Ali Thouni. Islamic Architecture,Terminology 
of Islamic architecture and The Early Concept

12 Rafat Algadargi. 1995. Dialogue the Structural In the Art. London: Riad Al Rayes of Books and publishing

13 Yusif Sharif. 1982. The History of Architecture In Various Eras of Iraq. Baghdad.

60 | Journal of Islamic Architecture Volume 2 Issue 2 December 2012 